\title{
Experimental intestinal stress induced by duodenal distention in sheep ${ }^{*}$
}

\author{
B.F. Kania ${ }^{1}$, Malgorzata Zaremba-Rutkowska' \\ and Katarzyna Romanowicz ${ }^{2}$
}

\author{
'Department of Pharmacology and Toxicology, Faculty of Veterinary Medicine, \\ Warsaw Agricultural University \\ Nowoursynowska 166, 02-787 Warsaw, Poland \\ ${ }^{2}$ The Kielanowski Institute of Animal Physiology and Nutrition. \\ Polish Academy of Sciences \\ 05-llo Jabtonna, Poland
}

(Received 24 July 1998; accepted 19 March 1999)

\begin{abstract}
The effect of various degrees of 5 min duodenum distention (performed with a balloon filled with $20,30,40$ or $80 \mathrm{ml}$ of water, DD 20-DD 80) on spike bursts and motility of the forestomach and abomasum was investigated in sheep which, under general anaesthesia, had clectrodes inserted into the muscular layers of the forestomachs, abomasum and duodenum, as well as into fistulas in the muscular layers of the rumen.

Duodenal distention of DD 20 to DD $30 \mathrm{ml}$ did not change the frequency of spike bursts or reticulo-ruminal motility, but significantly increased the amplitude of contractions $(F=74.40$ and $\mathrm{F}=110.02 ; \mathrm{P}<0.001$, respectively). In some animals a change in behaviour was observed (the animals shifted their weight from one foot to the other, urinated and/or defecated, looked around). Five min duodenal distention of DD 40 and DD 80 caused immediate and complete inhibition lasting for about $10 \mathrm{~min}$ of both the frequency of spike bursts and reticulo-ruminal contractions $(\mathrm{F}=43.46 ; \mathrm{P}<0.001$ and $\mathrm{F}=44.37 ; \mathrm{P}<0.001$, respectively) as well as of the amplitude of contractions $(\mathrm{F}=142.25$ and $\mathrm{F}=236.48 ; \mathrm{P}<0.001$, respectively). All animals showed the following signs: stretching their bodies, bleating, gnashing of teeth, lying down, urinating and defecating. Blood plasma cortisol level increased significantly during gastrointestinal motility inhibition from $16.23 \pm 1.12$ to $42.7 \pm 7.2$ $(\mathrm{F}=58.88 ; \mathrm{P}<0.001)$ during $\mathrm{DD} 40$ and from $19.58 \pm 1.81$ to $56.6 \pm 5.7 \mathrm{ng} \cdot \mathrm{ml}^{-1} 30 \mathrm{~min}$ after the end of DD $80 \mathrm{ml}(\mathrm{F}=25.47 ; \mathrm{P}<0.001)$.

Duodenal distention inhibited forestomach motility proportionately to the degree of distention $(\mathrm{F}=31.87 ; \mathrm{P}<0.001)$. This reaction is called the viscero-visceral inhibitory reflex. Morcover, it caused
\end{abstract}

\footnotetext{
* Supported by State Committee for Scientific Research, Grant No 5PO6K030I
} 
a change in animal behaviour and a significant increase in the plasma cortisol concentration, testifying to the fact that this is a general reaction to pain as a stressor.

The obtained results show that the model is sufficient to cause stress. It also allows the gradation of stress intensity. It can be concluded, therefore, that the above model can be used in testing anticolic drugs.

KEY WORDS: gastric motility, duodenal distention, cortisol, sheep

\section{INTRODUCTION}

A moderate degree of mechanical duodenal distention in sheep reduced the frequency of forestomach and abomasum contractions by 45 and $52 \%$, respectively, whereas strong distention provoked total contraction inhibition (Brikas et al., 1993). In conscious humans and animals this phenomenon is accompanied by acute visceral pain (De Ponti et al., 1987; Kania and Zaremba, 1998b). At the same time, in anaesthetized animals there is a strong increase of blood pressure. This is a test of the stressing action of nociceptive factor (Moss and Sanger, 1990). It proves that there is a direct relationship between the viscero-visceral reflex and visceral pain (Brikas et al., 1993), however, in literature this phenomenon in animals is limited only to the inhibitory viscero-visceral reflex (Iggo and Leek, 1967; Davison et al.,1984; Azpiroz and Malagelada, 1990; Holzer and Raybould, 1992). It is worth recalling that visceral pain as a reaction to non-physiological endo- and exogenous stimulus causes not only the inhibitory viscero-visceral reflex, but also activates the reactions of the hypothalamo-pituitaro-suprarenal system and subcortical structures, causing a general defensive reaction. In short, it is necessary to assume that pain of adequate intensity acts as a stressor.

From the clinical point of view, stress is a general (systemic) state which results from long-lasting stressor activity. Stress is also caused by pain, particularly intensive pain originating from the visceral wall, which is clinically diagnosed as one of the basic symptoms accompanying gastric or intestinal distention (colic) caused by the accumulation of gases or retained gastrointestinal contents. The general signs of visceral pain, considered to be a stress inducing factor, are primarily changes in animal behaviour such as the loss of appetite, head shaking, moaning, bellowing, staring at the side of the stomach wall from which the pain originates, urination, defecation.

According to the classical stress theory (Canon, 1927; Selye, 1934) the physiological reaction to a stressor is an alarm reaction, during which a few min of sympathicotony is observed. It is expressed by the release of adrenal gland CA as a consequence of stimulation of the sympatho-medullo-adrenal system. If the pain stressor reaches a certain intensity and duration then there is activation of the hypothalamo-pituitary-adrenal axis. At that phase of stress stimulation, release of 
hypothalamic corticoliberine (CRF) is increased. This causes the release of increased amounts of hypophyseal ACTH which, in turn, intensifies the secretion of glycocorticoids from the adrenal cortex (cortisol, corticosterone), reaching a maximum within 30 to $60 \mathrm{~min}$ after onset of the stress (Dallman and Jones, 1973; Radostis et al., 1994).

The mediators and modulators of the peripheral reaction to stressing factors are $\mathrm{E}, \mathrm{NE}$ and adrenal corticoids. The transmitters and modulators of the central reaction to stressors are such humoral factors as endorphins, enkephalins, 5-hydroxytryptamine (5-HT), histamine, CA, peptide hormones, neuropeptides, hypothalamic liberines, prostaglandins, substance P (SP), gamma amino-butyric acid (GABA) and other substances. Intestinal stressors (physical, bacteriological, toxic) of a particular intensity cause hypotony or atony of the digestive tract as a whole, particularly of the forestomachs.

Scientists believe that apart from the above-mentioned substances, an important role in this phenomenon is played by a high concentration of CCK that in itself inhibits forestomach motility (Kania et al., 1995) and food ingestion (Kania and Zaremba-Rutkowska, 1998a).

The aim of the present investigation was to disprove the hypothesis that duodenal distention that inhibits reticulo-ruminal motility only has a local inhibitory effect on gastrointestinal motility (viscero-visceral reflex). We show that it also causes general stimulation of the organism, of the alarm reaction to stress type (intestinal stress). Thus, the dependence between various rates of duodenal distention and inhibition of forestomach and abomasal motility as well as the general behaviour of sheep, and cortisol concentration in their blood plasma were investigated.

\section{MATERIAL AND METHODS}

\section{Preparation of animals}

Six adult, non-lactating Merino ewes of $36-45 \mathrm{~kg} \mathrm{BW}$ were used in the experiments. Two methods were applied: electromyographical and mechanical. The preparations for electromyographical registration included: after $24 \mathrm{~h}$ of fasting and intravenously administered thiopental (Nesdonal, $20 \mathrm{mg} \cdot \mathrm{kg}^{-1} \mathrm{BW}$ ) anaesthesia, pairs of nichrome electrodes with a 3-mm gap were inserted into the muscular layers of the reticulum, dorsal and/or caudoventral sac of the rumen, and the abomasum ( $4 \mathrm{~cm}$ from the pylorus) (Ruckebusch, 1970). The free ends of the electrodes were brought out through the abdominal wall on the right flank. In another group of animals the preparations for mechanographical motility registration included $24 \mathrm{~h}$ fasting and the same intravenously administered thiopental anaesthesia and then creation of a fistula in the ruminal wall, a technique previously described (Kania 
and Domański, 1996). A silicone T-shaped cannula (external diameter of $21 \mathrm{~mm}$ ) was inserted into the duodenum $12 \mathrm{~cm}$ from the pylorus. One jugular vein in every animal was permanently cannulated. After recovery from surgery the animals were placed in individual boxes or metabolic cages at constant temperature $\left(18-20^{\circ} \mathrm{C}\right)$ for at least 14 days prior to the beginning of the experiment.

\section{Myoelectric recordings}

Electrical activity of the investigated parts of the gastrointestinal tract was recorded $4 \mathrm{~h} /$ day on an electroencephalograph (Rega VII, Alvar) with constant time of $0.3 \mathrm{~s}$ and paper speed of $2.35 \mathrm{~cm} \mathrm{~min}^{-1}$, as previously described (Brikas et al., 1993). The frequency of reticulum, rumen (primary and secondary) and abomasum contractions was evaluated by counting the number of spike bursts on the electromyograms (EMG) for consecutive 5, 10 and 15 min periods before and 5, 10, $15,20,25$ and $30 \mathrm{~min}$ after the beginning of the duodenal distention (DD).

\section{Mechanographic recordings}

Reticulo-ruminal contractions were recorded on a tensometric recorder (COMT $\mathrm{o} /$ Białystok PIT 212). The mechanograms were analyzed and results calculated similarly as in the case of myoelectric recording (described above).

\section{Experimental procedure}

The experiments were performed twice a week on fasting animals. After 60 min of control recording of electric or motoric ruminal activity the animals were subjected to two periods of duodenal distention $(5 \mathrm{~min}$ each) produced by first introducing 20 and $30 \mathrm{ml}$ water and then 40 and $80 \mathrm{ml}$ water into a $10 \mathrm{~cm}$-long balloon which had been introduced into the duodenum through the fistula $30 \mathrm{~min}$ earlier. The last two levels of distention were chosen based on qualitative evaluation of general nociceptive symptoms noted in the animals (defecation, urination, head movements, abdominal cramps and flank observation). These symptoms were observed for the lowest duodenal distention with 20,30 and/or $40 \mathrm{ml}$ (DD 20, 30, 40), while either one or several were observed with $80 \mathrm{ml}$ distention (DD 80).

\section{Cortisol concentration}

One week before the experiment a cannula was permanently inserted in the jugular vein of each animal. On the day of the experiment $8 \mathrm{ml}$ blood was collected from the jugular vein for the determination of plasma cortisol concentration; the samples were prepared for assay and frozen. Sampling was as follows: a control 
sample was drawn 30 min after the duodenal placement of the balloon and an experimental sample was taken 30 min after DD 40 and DD 80. Plasma cortisol concentration was determined by RIA (Stupnicki, 1979; Przekop et al., 1985; Domański et al., 1986).

\section{Statistical analysis}

Statistical analysis of results was performed using one-way analysis of variance (ANOVA) and by comparing the control values with those observed after each distention using the Tukey-Kramer multiple comparison test. Results were expressed as means \pm SEM on the basis of data from two experiments performed on each of six ewes $(\mathrm{N}=12)$. The accepted significance level was $\mathrm{P}<0.05$.

\section{RESULTS}

Ten min before duodenal distention in fasting animals the mean frequency of reticular spike bursts was $1.2 \pm 0.12 \mathrm{~min}^{-1}($ mean $\pm \mathrm{SEM}, \mathrm{N}=12)$ while those of the rumen (primary and/or secondary contractions) and abomasum amounted to $1.5 \pm 0.25$ and $5.01 \pm 0.36 \mathrm{~min}^{-1}$, respectively (Figure 1 ). These values did not differ

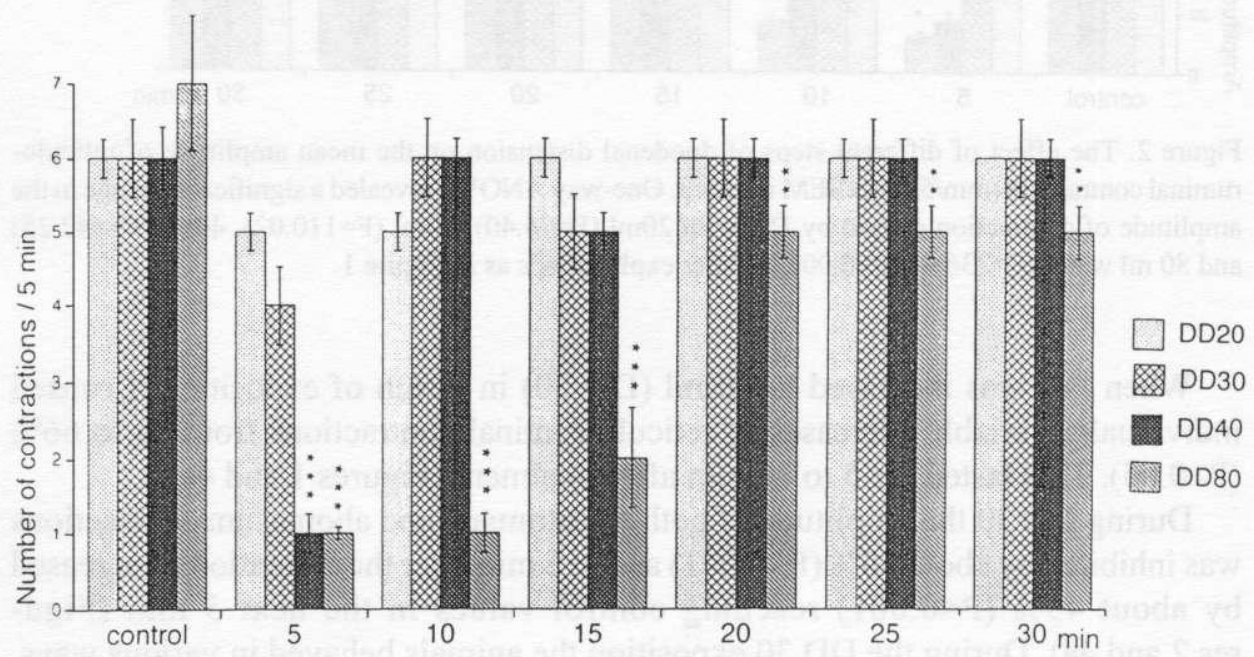

Figure 1. Comparative influence of different degree of duodenal distension (DD) on the mean number of reticulo-ruminal contraction (c/5 min) \pm SEM in sheep. The data were collected before DD (control) and at 5 min intervals after DD (dotted columns) from two experiments performed on six ewes a week apart. One-way ANOVA revealed a significant decrease in forestomach motility induced by DD with 40 and $80 \mathrm{ml}$ water $(\mathrm{F}=43.46, \mathrm{P}<0.001)$ and $(\mathrm{F}=44.37, \mathrm{P}<0.001$ respectively $)$, but not with lower volume 
significantly $(\mathrm{P}>0.05)$ from those observed before balloon insertion into the duodenum.

During DD 20, both forestomach spiking activity and reticulo-ruminal motility were partly inhibited with their frequency decreasing by approximately $16 \%(\mathrm{P}>0.05)$ for $3 \mathrm{~min}$, however, the amplitude of contractions increased significantly from $10.01 \%$ in 5 min after the termination of duodenal distention to $108.8 \%(\mathrm{P}<0.001)$ from 10 to $25 \mathrm{~min}$ after the DD 20 (Figure 2). No changes in general behaviour of animals were observed.

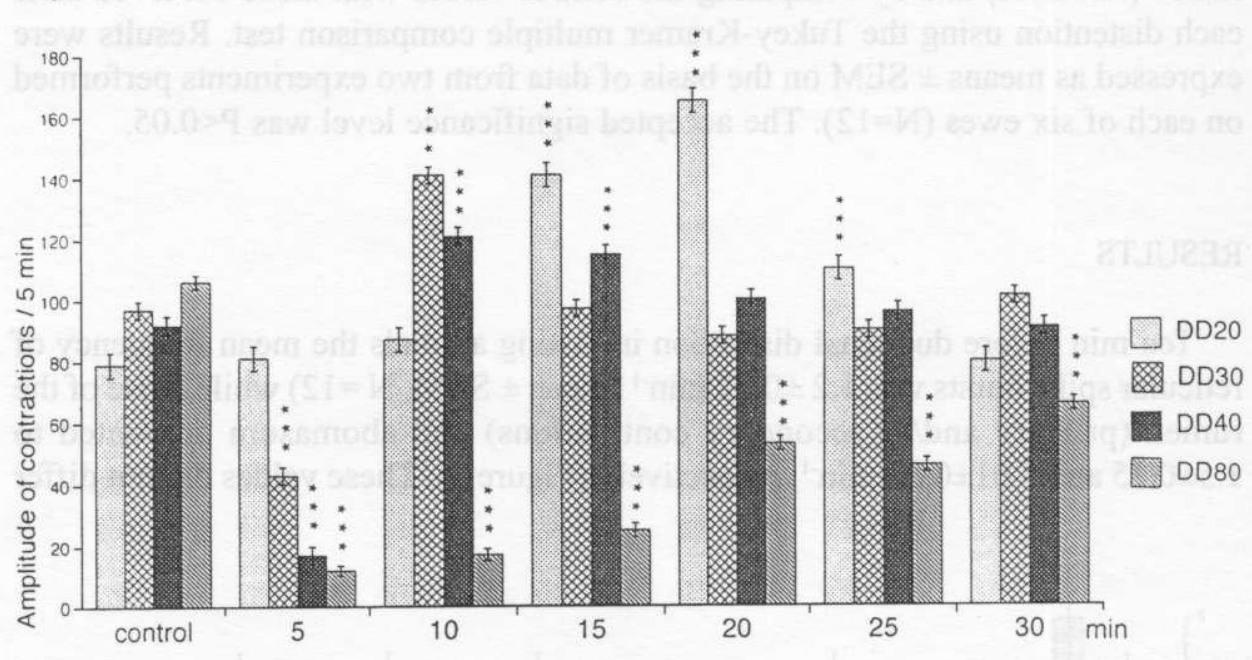

Figure 2. The effect of different steps of duodenal distension on the mean amplitude of reticuloruminal contraction $(\mathrm{mm} / 5 \mathrm{~min}) \pm \mathrm{SEM}$ in sheep. One-way ANOVA revealed a significant change in the amplitude of contraction caused by DD with $20 \mathrm{ml}(\mathrm{F}=74.40), 30 \mathrm{ml}(\mathrm{F}=110.02), 40 \mathrm{ml}(\mathrm{F}=142.25)$ and $80 \mathrm{ml}$ water $(\mathrm{F}=236.48, \mathrm{P}<0.001)$. Other explanations as in Figure 1

When DD was increased to $30 \mathrm{ml}$ (DD 30) in $5 \mathrm{~min}$ of exposition it caused individually variable decreases of reticulo-ruminal contractions from 33 to $66 \%$ $(\mathrm{P}>0.05)$. This lasted for 5 to $10 \mathrm{~min}$ after treatment (Figures 1 and $4 \mathrm{a}$ ).

During DD 30 the amplitude of both forestomach and abomasum contractions was inhibited by about $56 \%(\mathrm{P}<0.001)$ and in $5 \mathrm{~min}$ after the distention it increased by about $45 \%(\mathrm{P}<0.001)$ reaching control values in the next $5 \mathrm{~min}$ (Figures 2 and 4a). During the DD 30 exposition the animals behaved in various ways. Some of them defecated and/or urinated, moved their heads and watched their flanks. Immediately after the experiment the animals calmed down, assuming physiological position.

When the duodenal distention was caused by a $10 \mathrm{~cm}$-long balloon containing 40 $\mathrm{ml}$ (DD 40) water almost immediate (lasting 3 min during 5 min exposition) total 


\section{a}

Reticulum

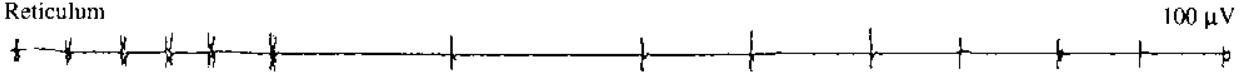

Dorsal rumen

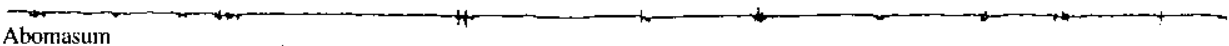

Abomasum

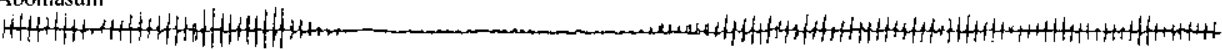

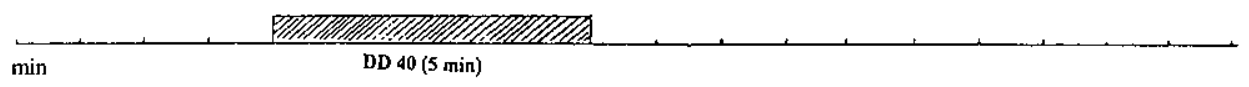

b
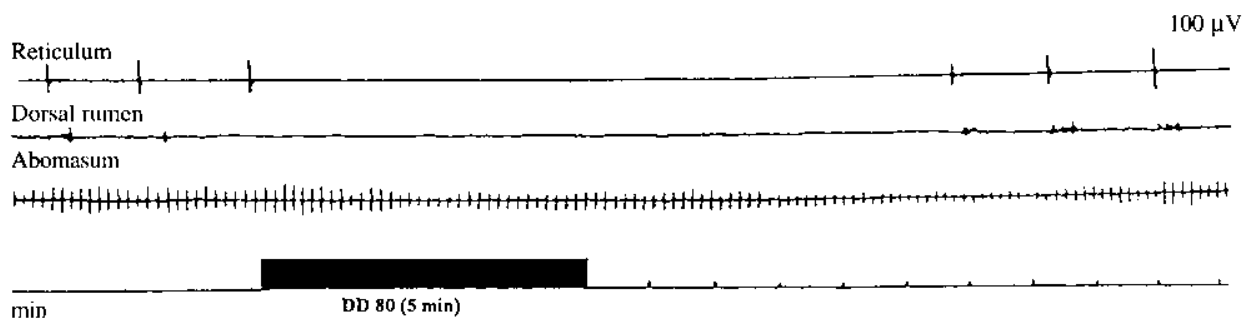

Figure 3. Electromyogram of the reticulum, dorsal sac of the rumen and abomasum in sheep showing the inhibitory influence of the duodenal distension with a balloon inflated with 40 (Figure $3 \mathrm{a}$ ) and $80 \mathrm{ml}$ water (Figure $3 \mathrm{~b}$ ) on the spike bursts in the wall of forestomachs and abomasum. Time $-1 \mathrm{~min}$

inhibition of reticulo-ruminal contractions was observed $(\mathrm{P}<0.001)$. During this 5 min distention, one or more than two contractions of eructation were observed in 6 animals (each tested twice) (Figures 1, 3a and 4b). After the termination of DD 40 contractions almost immediately reappeared, but their number did not match the number of control contractions (Figures 3a and 4b). During a 5 min episode of DD 40, the amplitude of both the forestomach and abomasum contractions decreased by approximately $81 \%(\mathrm{P}<0.001)$ and 5 and $10 \mathrm{~min}$ after was significantly increased: by 31.5 and $25 \%(\mathrm{P}<0.001)$, respectively (Figures $2,3 \mathrm{a}$ and $4 \mathrm{~b}$ ). During DD 40 , generalized symptoms of nociceptive reflexes were observed in the animals (bleating maintained even after DD termination, flank observation, head movements, urination and defecation, hyperventilation).

During DD 80, immediate and total inhibition of reticulo-ruminal contractions was observed for approximately $15 \mathrm{~min}$ (Figures $1,3 \mathrm{~b}$ and $4 \mathrm{c}$ ). Within $30 \mathrm{~min}$ after DD 80 termination the frequency of contractions was decreased by about $28.6 \%$ $(\mathrm{P}<0.01$; Figure 1$)$. The amplitude of both forestomach and abomasum contraction decreased on average by $86.8 \%$ during and $5 \mathrm{~min}$ after the end of DD 80 $(\mathrm{P}<0.0001)$ but was still approximately $56 \%(\mathrm{P}<0.0001)$ even $20 \mathrm{~min}$ after DD 80 

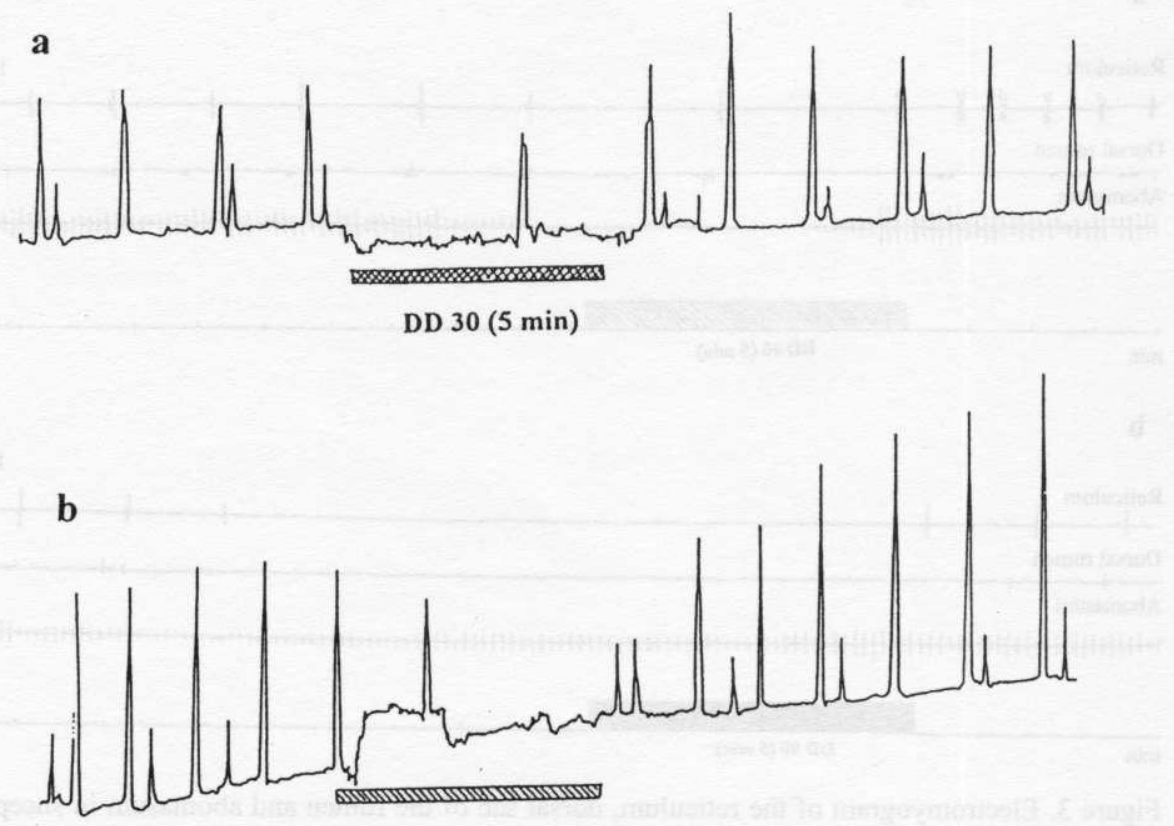

DD 40 (5 min)

c

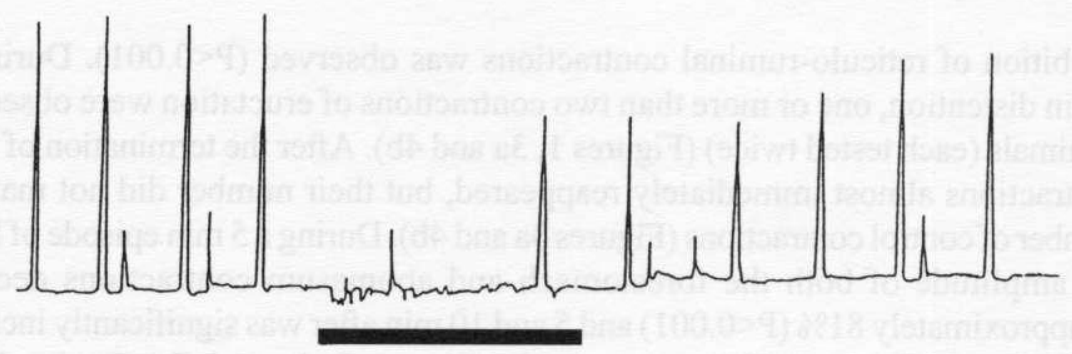

DD 80 (5 min)

Figure 4. Inhibitory influence of $5 \mathrm{~min}$ duodenal distension with a balloon filled with $30 \mathrm{ml}$ (DD 30 , Figure 4a); $40 \mathrm{ml}$ (DD 40, Figure 4b) and $80 \mathrm{ml}$ water (DD 80, Figure 4c) on reticulo-ruminal motility mechanografically registered in sheep. Time $-1 \mathrm{~min}$

(Figures 2, 3b and 4c). Apart from the changes observed with DD 40, in case of DD 80 the general behaviour of animals also included alternative lying down and rising, gnashing of teeth ( 5 min after the end DD 80), hyperventilation (from 20 to 88 breaths per min $8 \mathrm{~min}$ after the end of DD 80 ). During the experiment the animals stretched their bodies, arched their backs and dropped their heads at the 


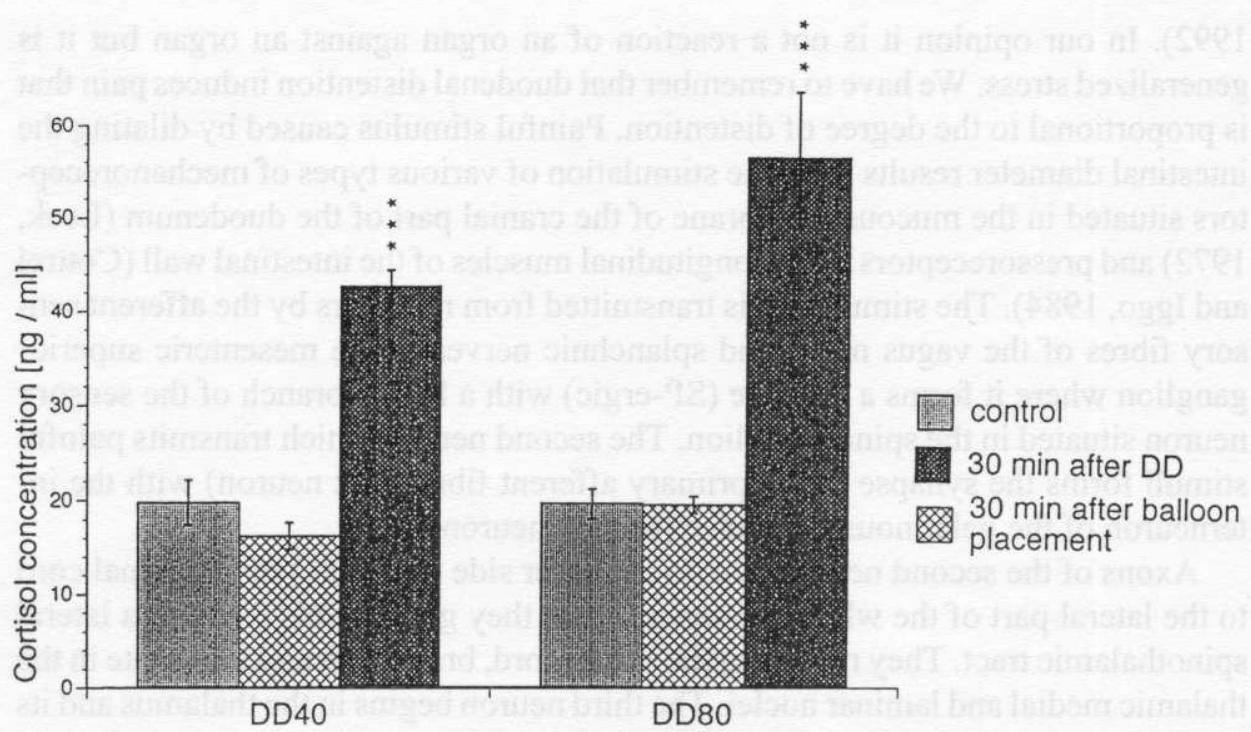

Figure 5. Effect of $5 \mathrm{~min}$ duodenal distension with a balloon filled with 40 (a) and $80 \mathrm{ml}$ water (b) on blood plasma cortisol level ( $\mathrm{ng} \cdot \mathrm{ml}^{-1} \pm \mathrm{SEM}, \mathrm{n}=6$ ) in comparison with the control values $(30 \mathrm{~min}$ after the balloon duodenal placement) in sheep. Table 1

same time, creating the impression of content that probably is related to $\beta$-endorphin release (Przekop et al., 1985).

Analysis of cortisol concentrations before, during and after the end of DD episodes showed significant increases 15-30 min after the end of DD. The rise in concentration was proportional to the DD level (Figure 5). During DD 40 the plasma cortisol concentration increased significantly by approximately $163 \%(\mathrm{~F}=58.88$; $\mathrm{P}<0.001$ ) $30 \mathrm{~min}$ after the end of DD 40 (from $16.23 \pm 1.43$ to $42.7 \pm 1.7 \mathrm{ng} \mathrm{ml}^{-1}$ ). In the case of DD 80, plasma cortisol concentration significantly increased from $19.58 \pm 2.20 \mathrm{ng} \mathrm{ml}^{-1}$ during the episode to $56.6 \pm 17.39 \mathrm{ng} \mathrm{ml}^{-1}(\mathrm{~F}=25,47 ; \mathrm{P}<0.001)$, i.e. $189 \%$ on average, $30 \mathrm{~min}$ after the end of DD 80 .

\section{DISCUSSION}

On the basis of results obtained in the present investigation it can be concluded that mechanical distention of the duodenum that imitates clinically diagnosed intestinal tympany (or colic) is an adequate stressor for provoking a general alarm reaction and adrenal cortex response proportional to the degree of duodenal distention. Acute duodenal distention caused hypotony of the forestomach and abomasum. Some authors call this reaction the viscero-visceral inhibitory reflex during duodenal distention (Iggo and Leek, 1967; Andrews and Lawes, 1984; Cottrell and Iggo, 1984; Davison et al., 1984; De Ponti et al., 1987; Hõlzer and Raybould, 
1992). In our opinion it is not a reaction of an organ against an organ but it is generalized stress. We have to remember that duodenal distention induces pain that is proportional to the degree of distention. Painful stimulus caused by dilating the intestinal diameter results from the stimulation of various types of mechanoreceptors situated in the mucous membrane of the cranial part of the duodenum (Leek, 1972) and pressoreceptors in the longitudinal muscles of the intestinal wall (Cottrel and Iggo, 1984). The stimulation is transmitted from receptors by the afferent sensory fibres of the vagus nerve and splanchnic nerves to the mesenteric superior ganglion where it forms a synapse (SP-ergic) with a lateral branch of the sensory neuron situated in the spinal ganglion. The second neuron which transmits painful stimuli forms the synapse of the primary afferent fibre (first neuron) with the interneuron of the gelatinous substance (second neuron).

Axons of the second neuron pass to the other side (opposite) of the spinal cord to the lateral part of the white substance. Then they go upwards forming a lateral spinothalamic tract. They run along the spinal cord, brain stem and terminate in the thalamic medial and laminar nuclei. The third neuron begins in the thalamus and its processes reach the cerebral cortex either directly (as specific tracts) or indirectly (diffused projection). The spinothalamic tracts send the collaterals to the reticular formation neurons. Thus, the appearance of symptoms of stimulation of the autonomic nervous system such as mydriasis, intense sweating, epinephrinemia, elevated blood glucose, hyperventilation, nausea, vomiting, tachycardia, and gastrointestinal tract hypotony are accompanied by intense visceral pain. The increased epinephrine concentration is a short-lasting "all or nothing" endocrine reaction of the adrenal medulla nervous system to the stressor in a situation that requires an immediate response on the part of the organism. A long lasting action of a damaging factor (noxa-e.g. strong, long lasting pain) provokes a response of the adrenal cortex releasing glucocorticoids as adaptive hormones in response to hypothalamohypophyso-corticosuprarenale axis stimuli.

The results presented in this paper indicate that duodenal distention is a new method of experimental intestinal stress provocation reproducing the action of a mechanical stressor. Up to now it has been believed that it is only a viscero-visceral reflex. The presented method imitates the clinical case of intestinal tympany leading to neurohumoral forestomach atony in sheep. It can be used as an experimental model in the study of the prophylactic and/or therapeutic effects of stress mediator antagonists. Apart from CA and histamine released in stress (Wieczorek and Niezgoda, 1997; Niezgoda et al., 1998) the authors also intend to verify CCK participation (Kania et al., 1994, 1995, 1998a), which is supposed to play a very important role in the mechanisms of CA and opioid release and the state of stress, especially intestinal stress, as some researchers hold the opinion that CCK is only an intestinal hormone and as such, plays a most important role, especially in digestion and food intake. 


\section{CONCLUSIONS}

Mechanical duodenal distention in sheep caused inhibition of both electrical and mechanical reticular and ruminal motility which was proportional to the degree of distention $(\mathrm{P}<0.0001)$.

Duodenal distention ( 40 and $80 \mathrm{ml}$ water) caused immediate and complete inhibition of forestomach activity/motility both in the number $(\mathrm{F}=31.87)$ and amplitude $(\mathrm{F}=116.23)$ of contractions $(\mathrm{P}<0.0001)$.

The syndrome of general behaviour symptoms, changes in heart beat and ventilation frequency as well as changes in plasma cortisol concentrations in the experimental animals show that duodenal distention in sheep (DD 40 and DD 80) is an adequate stressor for provoking forestomach atony and can be used to test antagonists of intestinal stress mediators.

Mechanographical recording of changes of the effect of duodenal distention on forestomach motility permitted more accurate observations of intragastric pressure changes and the amplitude of single contractions, whereas electromyographic recording often masks these changes because of quite high calibration during the recording of spike bursts on the part of the gastric muscular wall.

\section{REFERENCES}

Andrews P.L.R., Lawes I.N.C.,1984. Interaction between splanchnic and vagus nerves in the control of mean intragastric pressure in the ferret. J. Physiol. (London) 351, 473-490

Azpiroz F., Malagelada J.R., 1990. Perception and reflex relaxation of the stomach in response to gut distension. Gastroenterology 98, 1193-1198

Brikas P., Kania B.F., Fioramonti J., Bueno L., 1993. Central and peripheral serotonergic influences on viscerovisceral inhibitory reflex during duodenal distension in sheep. Dig. Dis. Sci. 38, 10791086

Cottrell D.F., Iggo A., 1984. Tension receptors with vagal afferent fibres in the proximal duodenum and pyloric sphincter of sheep. J. Physiol. (London) 354, 457-475

Dallman M.F., Jones M.T., 1973. Corticostcroid fcedback control of ACTH secretion: effect of stress-induced corticosterone secretion in subsequent stress response in the rat. Endocrinology $92,1367-1375$

Davison J.S., Hodges M., Dickson V., 1984. The enterogastric reflex in the ferret. Dig. Dis. Sci. 29, 558

Domański E., Przekop F., Wolińska-Witort E., Mateusiak K., Chomicka L., Garwacki S., 1986. Differential behavioural and hormonal responses to two different stressors (footshocking and immobilisation) in sheep. Exp. Clin. Endocrinol. 88,165-172

Hôlzer H.H., Raybould H.E., 1992. Vagal and splanchnic sensory pathway mediate inhibition of gastric motility induced by duodenal distension. Amer. J. Physiol. 262, G603-G608

Iggo A., Leek B.F., 1967. An electrophysiological study of some reticuloruminal and abomasal reflexes in sheep. J. Physiol. (London) 193, 95-119

Kania B.F., 1994. The effect of cholecystokinin (CCK-8) infused into the lateral cerebral ventricle on the functional electric activity of the forestomachs in sheep. Ann. Warsaw Agric. Univ. -SGGW, Vet. Med. 19, 99-106 
Kania B.F., Domański E., 1996. Central adrenergic pathway participation in the inhibitory effects of endorphins on forestomach motility in sheep. Small Ruminant Res. 19, 247-254

Kania B.F., Zaremba-Rutkowska M., 1998a. Participation of peripheral cholecystokinine receptors (CCK-A) in the central control of forestomachs electrical activity and food intake in sheep (in Polish). Med. wet. 54, 628-632

Kania B.F., Zaremba-Rutkowska M., 1998b. Duodenal distension as an animal model of the acute physical stress. XIII Congress of the Polish Pharmacological Society, Katowice (Poland). Pol. J. Pharmacol. 50, Suppl., p. 146

Kania B.F., Zaremba-Rutkowska M., Karlik W., 1995. Cerebral control of food intake and gastric motility by the cholecystokinin CCK-A receptor in sheep. XII Congress of Polish Pharmacological Society, Bydgoszcz (Poland). Pol. J. Pharmacol., Suppl. 1, p. 75

Leek B.F., 1972. Abdominal Visceral Receptors. In: E. Neil (Editor). Handbook of Sensory Physiology. Vol. III/1. Springer-Verlag, Berlin, pp.113-160

Moss H.E., Sanger G.J., 1990. The effects of granisetron, ICS 205-930 and ondansetron on the visceral pain reflex induced by duodenal distension. Brit. J. Pharmacol.100, 497-501

Niezgoda J., Wrońska-Fortuna D., Wieczorek E., Bobek S., Pierzchafa-Koziec K., 1998. Response of sympathoadrenal and hypothalamo-pituitary-adrenal axes of sheep on recurrent emotional stress (in Polish). Med. wet. 54, 334-337

De Ponti F., Azpiroz F., Malagelada J.R., 1987. Reflex gastric relaxation in response to distension of the duodenum. Amer. J. Physiol. 252, G595-G601

Przekop F., Stupnicka E., Wolińska-Witort E., Mateusiak K., Sadowski B., Domański E., 1985. Changes in circadian rhythm and suppression of plasma cortisol level after prolonged stress in sheep. Acta Endocrinol.110, 540-546

Radostis O.M., Blood D.C., Gay C.C., 1994. Veterinary Medicine. 8th Edition. Bailliére Tindall, London, pp. $60,64,99$

Ruckebusch Y., 1970. The electrical activity of the digestive tract of the sheep as an indication of the mechanical events in the various region. J. Physiol. (London) 210,857-882

Sorraing J. M., Fioramonti J., Bueno L., 1985. Central and peripheral serotonergic control of forestomach motility in sheep. J. Vet. Pharmacol. Ther. 8, 312-319

Stupnicki R., 1979. Radiommunoasay of Cortisol (in Polish). In: F. Kokot, R. Stupnicki (Editors). Radiommunoasay and Radiocompetition Methods Applied in Clinics. PZWL, Warszawa (Poland), pp. 203-211

Wieczorek E., Niezgoda J., 1997. Interrelationships between hypothalamo-hypophiso-gonadal system in female (in Polish). Med. wet. 53, 707-710

\section{STRESZCZENIE}

\section{Doświadczalny stres jelitowy powodowany rozszerzeniem dwunastnicy u owcy}

Badano wpływ różnego stopnia rozszerzenia dwunastnicy (wykonanego balonikiem wypełnionym 20, 30, 40 lub $80 \mathrm{ml}$ wody - DD 20 -- DD 80) na motorykę i aktywność mioelektryczną przedżołądków i trawieńca. Owcom, w czasie znieczulenia ogólnego, w mięśniówkę przedżołądków i trawieńca oraz dwunastnicy zaimplantowano elektrody oraz przetoki do dwunastnicy i żwacza.

Rozszerzanie dwunastnicy - DD 20 i DD $30 \mathrm{ml}$ - nie powodowało zmian w częstotliwości wyładowań i motoryki czepco-żwacza, ale powodowało istotne zwiększenie amplitudy skurczów (odpowiednio $\mathrm{F}=74,40$ and $\mathrm{F}=110,02, \mathrm{P}<0,00 \mathrm{l}$ ). $\mathrm{U}$ niektórych zwierząt obserwowano zmiany 
w zachowaniu (przestępowanie z nogi na noge, oddawanic kału i moczu, rozglądanie się dookoła). $\mathrm{Z}$ drugiej strony 5-cio minutowe rozszerzanie dwunastnicy - DD 40 i DD 80 - powodowało prawie natychmiastowe i całkowite hamowanie częstotliwości wyładowań i motoryki czepco-żwacza trwające około 10 minut $(\mathrm{F}=43,46 \mathrm{P}<0,001$ and $\mathrm{F}=44,37, \mathrm{P}<0,001)$ oraz amplitudy skurczów $(\mathrm{F}=142,25$ i $\mathrm{F}=236,48, \mathrm{P}<0,001)$. Wszystkie zwierzęta wykazywały następujące objawy: przeciagaly się, zgrzytały zębami, pokładały się, oddawały kał i mocz. Podczas hamowania motoryki stężenie kortyzolu w osoczu krwi zwiększało się istotnie (od $16,23 \div 1,12$ do $42,7 \div 7,2 \mathrm{~F}=58,88, \mathrm{P}<0,001$ podczas DD 40 i od $19,58 \div 1,81$ do $56,6 \div 5,7 \mathrm{ng} \mathrm{ml}^{-1} 30$ min po zakończeniu $\mathrm{DD} 80 \mathrm{ml}(\mathrm{F}=25,47, \mathrm{P}<0,001)$.

Rozszerzenie dwunastnicy powodowało hamowanie motoryki przedżołądków proporcjonalnie do stopnia jej rozszerzenia $(\mathrm{F}=31,87, \mathrm{P}<0,001)$. Reakcję tę nazywano hamującym odruchem trzewno-trzewnym. Ponadto dochodziło do zmian w zachowaniu i statystycznie istotnego zwiększenia stężenia kortyzolu w osoczu co dowodzi, żc jest to reakcja ogólna organizmu na ból jako czynnik stresogenny.

Uzyskane wyniki wskazuja, że proponowany model jest wystarczający do prowokowania stresu. Pozwala też na stopniowanie jego intensywności. Prezentowany model może być przydatny do testowania leków o działaniu ,przeciwkolkowym" u zwierząt. 